\title{
SEMANTIC AND LINGUOCULTURAL FEATURES OF ENGLISH AND UZBEK PROVEBRS WITH CONCEPT OF FRIENDSHIP Abdullaeva N.E. Email: Abdullaeva1789@scientifictext.ru
}

\author{
Abdullaeva Nargiza Erkinovna - Senior Researcher, \\ DEPARTMENT OF ENGLISH PHILOLOGY, \\ NATIONAL UNIVERSITY OF UZBEKISTAN NAMED AFTER MIRZO ULUGHBEK, \\ TASHKENT, REPUBLIC OF UZBEKISTAN
}

\begin{abstract}
English and Uzbek proverbs about friendship. The equivalents of some proverbs in a target language are given for interpreting them in the other language to find out several important innovative ways of translation and contrasting their peculiarities in the English and Uzbek languages. The results and examples of this paper can help to distinguish some differences in the meanings of the English and Uzbek proverbs about friendship and to learn linguocultural peculiarities of them.
\end{abstract}

Keywords: proverb, linguoculturology, cultureme, pragmatics, synonymy, antonymy, equivalent, context.

\section{СЕМАНТИЧЕСКИЕ И ЛИНГВОКУЛЬТУРОЛОГИЧЕСКИЕ ОСОБЕННОСТИ АНГЛИЙСКИХ И УЗБЕКСКИХ ПОСЛОВИЦ С ПОНЯТИЕМ «ДРУЖБА» Абдуллаева Н.Э. Email: Abdullaeva1789@scientifictext.ru}

\author{
Абдуллаева Наргиза Эркиновна - старший научный сотрудник, \\ кафедра английской филологии, \\ Национальный университет Узбекистана им. Мирзо Улугбека, г. Ташкент, Республика Узбекистан
}

\begin{abstract}
Аннотация: данная статья посвящена анализу семантических лингвокультурологических черт некоторых английских и узбекских послович о дружбе. Эквиваленты некоторых пословиц в языке перевода предоставлены для их интерпретации на другом языке, чтобы выяснить несколько важных инновационных способов перевода и сопоставления их особенностей в английском и узбекском языках. Результаты и примеры этой статьи содействуют выявлению различительных оттенков в значениях английских и узбекских пословии о дружбе и определению их лингвокультурологических черт.
\end{abstract}

Ключевые слова: пословица, лингвокультурология, культурема, прагматика, синонимия, антонимия, эквивалент, контекст.

УДК 811.111-26:811.512.133

A language reflects the particular culture of its nation, especially, proverbs' role in reflecting national features and culture of this nation is considerable. Not only traditions of the people and national notions, but also historical places, outstanding people and famous characters of the nation are expressed in proverbs.

A proverb (from the Latin "proverbium" - proverb) is a popularly known, repeated and concrete saying with complete utterance; they express a truth, based on common sense or the practical experience of people. Prominent linguist W. Mieder gives a definition to a proverb in his book: "A proverb is a short, generally known sentence of the folk which contains wisdom, truth, morals, and traditional views in a metaphorical, fixed and memorisable form and which is handed down from generation to generation" [1, p. 27]. It is clear from the definition that proverbs are usually based on metaphor and have figurative meaning. Although several scholars give many definitions for the notion of a proverb, Mieder's definition is considered to be the best one among them. Because proverb is not a simple unit of a language, it is a ready-made sentence that gives metaphorical meaning with words of wisdom or traditional thoughts of people or nation. Besides, they have been created not only by an individual in a short period of time. A proverb is a product of the definite nation as a folk saying during considerable long time. They are handed down through years and ages as frames or models of human life typical situations. Ch. C. Doyle suggests investigating them as minimal folk poems [2, p. 4] in literature, because they enliven dialogues or give expressiveness and emotiveness to poetry or prose in various ways.

Folklore and linguistics study proverbs as their objects. Some scholars (Taylor, Seiler, Firth, Mieder, etc.) mentioned in their works that the main reason of studying proverbs in folklore is their traditionality. No doubt that folklore units are traditional and recurring; as N.R. Norrick points they are "seen as authorless, sourceless and also as non-literary, non-learned" [2, p. 10]. Proverbs own these features but not completely. However, they are also investigated as a folklore unit and differentiate form proverbial phrases, clichés, idioms, aphorisms, wellerisms, superstations, maxims and slogans.

Linguistics also distinguish proverbs form idioms and phrases; besides analyse them as sentences, clauses, conversational turns, speech acts, etc. A Proverb is considered as a phraseological unit with figurative meaning in linguistics and to be equal to a sentence according to a complete utterance that they can form in a speech. 
Moreover, their diverse expressiveness and emotiveness are obviously noticed during the process of conversation. Therefore, proverbs can represent the speech situation clearly.

The study of proverbs has application in a number of fields. However, proverbs have their own study field "paremiology" (from Greek "paroimia" - "proverb"). A number of scientific investigations have been done in or linking with this field. Still there are many issues to be analysed and defined by scholars. Comparing and contrasting proverbial stocks of different languages gives interesting and valuable scientific results. This work aims to investigate semantic and linguocultural features of proverbs in two languages: English and Uzbek, which do not belong to one language family. Moreover, this paper is illustrated with proverbs about friendship in these two languages being mentioned above.

Clearly, proverbs picture practically a great deal of details of the everyday life of even ordinary people. Many linguists have offered a method of discussing proverbs as cultural texts based on the linguocultural level of language and the cultureme as its basic structural unit. The term "linguoculturology" has been supposed to be used as a separate linguistic field since the beginning of the previous XX century. This field studies interrelation of language and culture, mutual influence on the development of culture and language, their links with social life, psychology, and philosophy. Because a language cannot exist without a culture of a nation and a culture also cannot survive without a language as well.

Linguoculturology is one of the main aspects of linguistic investigations, it deals with various issues that relate with language spirit and cultural variation of a nation, encompasses various national-cultural notions and theories of conversational structure. This branch studies national spirit that is reflected in a language. It is associated with other studies as philosophy, logics, sociology, anthropology and semantics; and covers nationalcultural knowledge through speech communication.

The appearance of linguocultural study considerably depends on the development of philosophic and linguistic theories during the XIX-XX centuries. In the last century, a number of research works were maintained in Russia. One of the well-known book belongs to V.A. Maslova called "Введение в лингвокультурологию" (Introduction to linguoculturology) [3]. The author defines research fields and methodological basis of contemporary linguoculturology deeply in her book. Her hypothesis are valuable to be applied in nowadays' new investigations not only about linguocultural problems, and also in other linguistic and philosophic branches.

Scientists that links to this linguistic branch make a great deal of investigations. V.N. Teliya writes that methodological basis of linguoculturology serves "semiotic presentation indications of this interaction, considered as cognitive contents of mental procedures, the result of which is cultural liqualization of mental structures" [4, p. 17]. According to this idea, linguocultural study is not isolated from other scientific branches. As it is a linguistic field it assists to the other branches of language learning and develop with the help of them.

In the book of Uzbek linguist U.K. Yusupov "Contrastive linguistics of the English and Uzbek languages" it is clearly mentioned that linguocultureme is a linguistic or speech unit defining one part of a culture; consequently linguoculturology is a branch of linguistics, which studies interrelation between language and culture, and conveying culture in a language [5, p. 262]. Still it is clarified that linguoculturology focuses attention onto the reflection of spiritual state in the language of a human in the society.

In general, this branch analyses cultural colours of linguistic units as well as it studies language through culture. Besides, linguoculturology possesses a number of following specific features:

1) it is a subject of synthetic type, occupying bordering position between science and, learners of culture and philology;

2) the main object of culturology is interrelation of language and culture and interpretation of this interaction;

3 ) as the subject of investigation of linguoculturology serves spiritual and material culture, verbalized artefacts, forming "the language picture of the world";

4) linguoculturology is oriented to the new system of cultural values, put forth by the modern life in the society, to the objective information on the cultural life of the country [6, p. 32].

Each subject or a branch of subject owns its studying object. The term "cultureme" (or "linguocultureme") is admitted to be used in scientific researches for naming the object of linguoculturology. The difference between cultureme and lexeme is recognized in its definition: cultureme is a word, phrase or even a full sentence in a language, which embraces national, social or mental peculiarities that are specific to the culture of the language.

Some scholars successfully distinguish subtypes of one language according to the types of culture layers:

1) literary language -élite culture;

2) popular language - "the third culture";

3) dialects and sayings - popular culture;

4) argot (words and expressions which are used by small groups of people and which are not easily understood by other people) - traditional-professional culture.

In this paper, the attention is focused to the contrastive study of proverbs that stay in the third component of this classification. 
It is obvious that appearing and forming of proverbs, besides, admitting them into live conversations by the nation takes sometimes considerably long period of time. The English and Uzbek languages are believed to have long history.

English has background that comes from the Latin language, therefore a huge number of English paremiologic stock have Latin bases; some of them are identical to the historical forms, some of them faced to changes in comparison with the old ones. Through many years, other languages have been affecting to the English language, too. As a result, some proverbs are often borrowed from them in the way of translating proverbs into English as well. W. Mieder introduces the four major sources four common European proverbs, including English, namely the Greek and the Roman Antiquity, the Bible, the Medieval Latin and the loan translations [2, p. 6].

The Uzbek language possesses also long background. It is true that this language was given the name of "Uzbek language" recently, but this language has existed since approximately X-XI century. A huge number of proverbs, sayings and aphorisms are considered as a great wealth of the Uzbek culture. The main sources may be classified as followings: some characters from religious sources and the borrowed translations (mainly from the Arab, Tadjik, Persian and Russian languages). Moreover, there are some proverbs that come from sayings created by the mass media (TV, radio or social nets), expressions of films and songs, and even advertising slogans in all languages including English and Uzbek. However, they need some time to become or to form new proverbs as well.

This paper aims to analyse linguo-cultural features of proverbs in these two languages with the help of examples about friendship. The concept of "friendship" is an abstract notion which is valuable in a human life that take place in the row of social concepts as "family", "health", "wealth" and "labour". Translating proverbs word-by-word is not sufficient way to express the meaning of a proverbs in the other languages because of culturemes that exists in its content in a target language. It may cause to misunderstand the basic meaning of a proverb. Therefore, the method of finding equivalents of proverbs in English and Uzbek is used to investigate peculiarities of proverbs about friendship in these languages.

(1) Birds of a feather flock together. - O'xshatmasdan uchratmas (They do not meet who do not look like each other).

The behaviour of birds is taken as a resemblance to the human friendship in the English proverb (1), while a short sentence structure with unknown subject is used in the Uzbek one. It is confessed that a sentence structure in which a subject is elliptical is characteristic of the nearly all proverbs belong to the Uzbek nation. In addition, according to the interesting fact that both proverbs, which are given above have Arabic origin (XVI century).

There are many synonym words and phrases in a language, proverbs can be synonymous to one another. Sometimes their meanings are similar and they can substitute one another in a context. However, many of synonym proverbs cannot be absolute synonyms even they resemble one another semantically. Because, expressiveness in their meanings differs in some degree from each other, consequently they are used in different cases and situations - so they own different pragmatic and sociolinguistic features: some of them are mostly applied in formal (official) cases while some of them often appear in informal (oral) conversations. Though the proverbs that given above have several synonyms they cannot substitute one another in a context, otherwise the semantic or stylistic balance would be destructed roughly.

(2) A man is known by the company he keeps. - Do'sting kimligini ayt, sening kimligingni aytaman (Tell me your friend, I shall tell who you are).

In these proverbs (2) it is said that man's qualities are determined by what kind of friends he has. In semantic point of view, these two proverbs seem identical, but their pragmatic features are different: the English proverb is usually used in more formal and literary styles, in its turn the Uzbek one is mostly applied in colloquial speech.

(3) There is no better looking-glass than an old friend. / The eye of a friend is a good mirror. - Do'st achitib gapirar, dushman kuldirib (A friend tells bitter (truth), an enemy sweet (lie)).

These proverbs (3) says that a true friend tells reality even you do not like it and they should tell you your mistakes or bad character, while enemies deceive you with sweet words in order to be liked or find your weak point. In these both English proverbs the lexeme of mirror (= looking-glass) is used. The Uzbek equivalent of these proverbs has the stylistic device of oxymoron (friend - enemy, bitter - sweet).

(4) A friend in court is better than a penny in purse. - Boylik boylik emas, birlik boylik (Wealth is not wealth, solidarity is wealth).

The main meaning of these proverbs (4) represents that friendship is more valuable or necessary than money, it is real wealth. The existence of the cultureme "penny" proves that it belongs to the English nation. The English culture compare friendship with the currency and it says friends are better than pennies; being friends is equalised to real wealth in the Uzbek one.

(5) It is good to have some friends both in heaven and hell. - Do'sting yoningda bo'lsa, ishing oson bitadi (While your friend is with you, you solve your problem fast). 
The English proverb (5) possesses strong expressiveness and impressiveness because of the culturemes "heaven" and "hell", at the same time they are religious words and semantic opposites (antonyms). The existence of these words represents the linguocultural and pragmatic peculiarities of this proverb. The proverb in Uzbek has more simple structure and literal meaning in comparison with the English one that owns figurative meaning.

(6) Be a friend to thyself and others will befriend thee. - O'ziga boqmagan, o'zgaga yoqmas (If one does not pay attention to himself (his character or behaviour), others do not like him).

There are old forms ("thyself", "befriend", "thee") of English words in the proverb (6), which belongs to the Old English. It shows that this proverb has long usage by the nation and nowadays it is still being used frequently. Both of these proverbs (6) mean that if a person respects himself and keeps himself from doing bad things, he gets many friends.

(7) Friends are made in wine and proved in tears. - Do'st kulfatda bilinar (A friend is tested in trouble).

The cultureme "wine" is given in the meaning of happiness and "tears" - sadness here as metaphor in this English proverb (7), on the other hand Uzbek variant gives this meaning with a short structure.

The several Uzbek equivalents of one English proverb are given in the following graph: 1-graph.

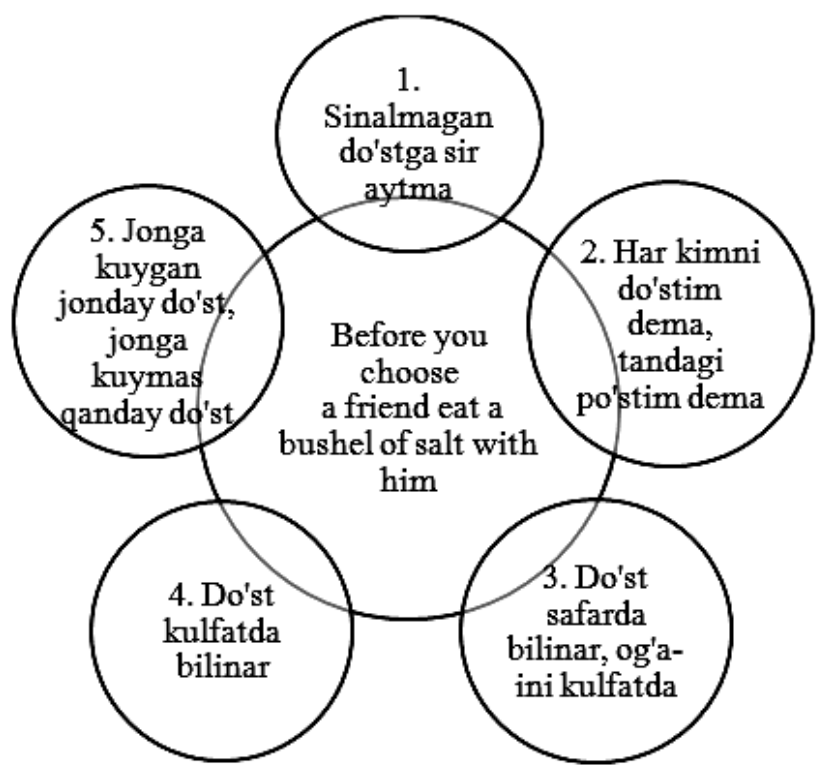

Fig. 1. Several Uzbek equivalents of one English proverb

Translations of these Uzbek proverbs:

1. Do not tell your secrets to your friend that has not been tested.

2. Do not consider everyone a friend as your skin on your body.

3. A friend is tested in a trip, brothers in trouble.

4. A friend is tested in trouble.

5. A close friend worries about your life, what a friend if he does not worry.

Representing difficulty or trouble in English proverb situating in the centre of the graph is fulfilled by using the expression of "eating a bushel of salt" (here "bushel" is also a cultureme). As a fact, its equivalents are many in Uzbek, and they have culturemes as well: "jonday", "og'a-ini". However, these proverbs are applied in different contexts according to social and pragmatic factors such as time, place, situation, case, etc.

The next graph represents several English equivalents of an Uzbek proverb: 2-graph. 


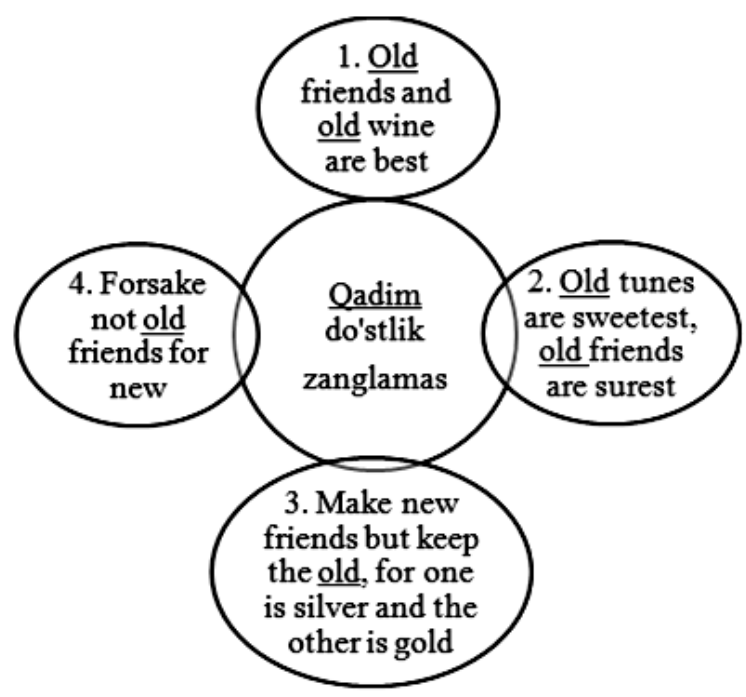

Fig. 2. Several English equivalents of an Uzbek proverb

Translation of the Uzbek proverb in this graph: Old friendship does not rust.

All proverbs in this graph has the lexeme "old" (in Uzbek "qadim, qadimgi, eski"), it shows that old friendship is estimated very valuable in both languages. In the English equivalent №3, old friends are equalised to gold, new friends to silver. On the other hand, even there is not a word "gold" in the Uzbek proverb, it has also this meaning according to the reason that gold never rusts and here in the proverb it is recognizable from the meaning. Moreover, each proverb represents different culturemes (wine, tune, silver, gold,) in its content and possesses various structural, stylistic and pragmatic features; even the usage of a proverb in different contexts can provide to have additional expressive or emotional meanings of proverbs.

Antonymous proverbs are found in many languages in the world. It is also characteristic to the proverbs with the concept of "friendship" in English and Uzbek. Several proverbs exist that have opposite meanings to the above given proverbs. For instance:

(8) The best of friends must apart. - O'rtada burun bo'lmasa, ko'z ko'zni o'yar (If there is not a nose between eyes, they cut out each other).

They (8) mean even the closest friends must forsake each other and friendship is not everlasting.

(9) A friend to everybody is a friend to nobody. - Ko'pni sevgan birni sevmas (If a person loves many (people), he loves none of them).

According to these proverbs (9) if someone is many people's friend, it means he is not anyone's real friend; true friends are very few in real life.

The most negative proverb about friends is following one:

(10) Friends are thieves of time. - Do'stingni saqlama yo 'ldan qolar, dushmanni saqlama siring olar (Do not waste your friend's time, he should go; do not keep your enemy, he will find out your secret).

The English variant of these proverbs (10) represents more touchable and stronger negative meaning than the Uzbek one.

As it was mentioned above the Uzbek language is considered to have rich stores of proverbs. Uzbek proverbs connected with the notion "friendship" are more than 400, while in English they are not more than a hundred. U.K. Yusupov explains the reasons of such kind of big quantity like these [5, 27]:

- firstly, the Uzbek people pay much attention to the notion "friendship" which is considered as one of the main relationships of humanity; examples:

Do'st otgan tosh bosh yormas (The stone does not hurt your head that was thrown by your friend).

Quyosh havoni isitar, do'st-qalbni (The sun heats the air, a friend heats a soul).

- secondly, the concept of "friendship" has wider meaning and requirements for friendship is more in the Uzbek culture than other cultures, that is why these peculiarities are expressed in the Uzbek proverbs; examples: Yaxshi ko'rgan do'stingga yaxshi ko'rgan molingni ber (Give your lovely thing to your lovely friend).

Do'sting uchun zahar yut (Eat poison for your friend).

- thirdly, there are many proverbs in which the concept of "friendship" is compared with the notion of "being enemies" in the Uzbek language; examples:

Dushmanni yengmoqchi bo'lsang, do'stingni ehtiyot qil (If you want to win your enemy, take care of your friend).

Dushmanning donidan do'stning somoni yaxshi (Friend's straw is better than enemy's corn). 
There are many Uzbek proverbs about friendship that their equivalents cannot be found in any other languages, the basic reason is that many Uzbek proverbs about friendship express the Uzbek culture and they have national culturemes:

Do'stsiz boshim - tuzsiz oshim (My head without friend - my palov (an Uzbek traditional meal) without salt).

Sipoxiydan oshnang bo'lsa, yoningda boltang bo'lsin (If your friend is a sipohiy (a type of a soldier in the Uzbek culture), you should carry an axe).

Mard kurashda bilinar, do'st tashvishda (A brave man is tested in kurash (an Uzbek sport), a friend in trouble).

To conclude, proverbs come to be a very numerous parts of the English and Uzbek languages. They differ semantically, structurally, stylistically and even pragmatically from one another. Proverbs cover many drawbacks of the culture of a nation. Proverbs serve to describe, define and express the culture of the language in which they exist. One can see national notions, things, feelings, traditions, well-known ancestors, even the names of places - cultural points in the paremiologic fund of a language.

English and Uzbek proverbs connecting with the concept of "friendship" reflects the mentality, culture and traditions of a nation and take important place in the language of this nation. In both languages, proverbs about friends are various, besides synonymous or antonymous proverbs can be found among them. But their synonymic and antonymic relations are not considered to be absolute, because they are chosen according to a context, as a result their meanings may be also slightly changed. Therefore, applying a proverb in an appropriate place makes a speech clear and fluent. Because as it was mentioned above, proverbs are often used in a speech and they are chosen according to time, place, case and other pragmatic factors. Besides, a society and social processes effect directly to the usage, semantic expressiveness and other features of proverbs.

The translation process of proverbs from one language into another requires more than componential or structural approach, it is necessary to give exactly main idea of a target proverb in a translation. As the main result of the paper it is proved that the semantic, structural or stylistic similarities are found between English and Uzbek proverbs about friendship as well as they have many differences. But resemblance between linguocultural peculiarities of these proverbs do not occur in these languages. Because they are not relative languages according to the genetic classification of world languages. Furthermore, every nation has its culture, tradition and, of course, culturemes reflecting the parts of the culture in this nation's language. These culturemes serve to provide original semantic and linguocultural features of proverbs.

In the view of the observations made above, it is important to point out that proverbs contain social practices that can be visualized in a real or possible world. Furthermore, a language always changes itself day by day, for that, the quantity of proverbs in it also changes; some proverbs may disappear, people may begin to use some other new proverbs in their conversations.

\section{Список литературы на английском языке / References in English}

1. Mieder W. International Proverb Scholarship. New York: Garland Publishing, 1993. P. 27-63.

2. Gotthardt H.H., Varga M.A. (eds.) Introduction to Paremiology: A Comprehensive Guide to Proverb Studies. Berlin: De Gruyter, 2014. P. 2-10.

3. Maslova V.A. Introduction to linguoculturology. Moscow, 1997.

4. Teliya V.N. Phraseology in the context of culture. Languages of Russian culture. Moscow, 1999. P. 17-20.

5. Yusupov U.K. Contrastive Linguistics of the English and Uzbek languages. Tashkent: Akademnashr, 2013. P. 27-262.

6. Vorobyov V.V. Lingua-culturological principals of presentation of educational material.The problems of concentrism. Moscow, 1997. P. 32-38.

7. Cruse D.A. Lexical Semantics. Cambridge: Cambridge University Press, 1986. P. 25-38.

8. Gryzberg P. Proverb. New York: Brockmeyer, 1994. P. 227-241.

9. Abrahams R.D. Proverbs and proverbial expressions. In R. M. Dorson (Ed.), Folklore and folklife. Chicago, 1972. P. 117-127.

10. Mieder W. Proverbs: A handbook. Westport, CT: Greenwood Press, 2004.

11. Mieder W., Litovkina A.T. Twisted wisdom: Modern anti-proverbs. Burlington: The University of Vermont, 1999.

12. Norrick N.R. How proverbs mean. Berlin: Mouton, 1985.

13. Taylor A. The proverb and index to "the proverb". Hatboro/ PA: Folklore Associates, 1962.

14. Eckert $P$. Linguistic variation as social practice. Malden/ MA: Blackwell, 2000. 